\title{
Management as a Domain-Relative Practice that Requires and Develops Practical Wisdom
}

\author{
Gregory R. Beabout \\ Saint Louis University
}

\begin{abstract}
Although Alasdair MacIntyre has criticized both the market economy and applied ethics, his writing has generated significant discussion within the literature of business ethics and organizational studies. In this article, I extend this conversation by proposing the use of MacIntyre's account of the virtues to conceive of management as a domain-relative practice that requires and develops practical wisdom. I proceed in four steps. First, I explain MacIntyre's account of the virtues in light of his definition of a "practice." Second, I examine his distinction between "practices" and "institutions." Third, I explain what I mean by a "domain-relative practice" and defend the claim that it is helpful to conceive of management in those terms. Finally, I highlight several features of practical wisdom as a virtue developed in and integral to standards of excellence within management as a domain-relative practice.
\end{abstract}

KEY WORDS: management, virtue, MacIntyre, practice, business ethics

$\mathrm{W}$ HEN ALASDAIR MACINTYRE WAS ASKED why he declined an invitation to address a conference on business ethics, he reportedly explained that he refused for the same reason that he "wouldn't attend a conference on astrology" (Knight 1998: 284). Because MacIntyre has been a long-time critic of the freemarket economy, it might seem a bit unusual to propose extending MacIntyre's virtue ethics into the area of management. After all, MacIntyre paints the bureaucratic manager as one of the key villains in the descent into the moral hollowness of contemporary culture.

In After Virtue, MacIntyre describes the manager as a "stock character" in "the social drama of the present age" (MacIntyre 2007: 27). MacIntyre narrates a history of the modern self, connecting the Cartesian ego, disembodied and disconnected from the world of space and time, to twentieth-century emotivism and the bureaucratic manager. Within this framework, MacIntyre conceives of the manager as an embodiment of the emotivist self - that is, the self "able to stand back from any and every situation in which one is involved, from any and every characteristic that one may possess, and to pass judgment from a purely universal and abstract point of view that is totally detached from all social particularity" (MacIntyre 2007: 31-32).

Drawing from Max Weber, the manager that MacIntyre has in mind is a "type": an office executive and career professional appointed on the basis of certifiable 
qualifications and compensated accordingly, charged with managing a specific, limited area to accomplish a given purpose according to written policies and rules, and applying those policies and rules in an impersonal manner within a hierarchical structure (Weber 1947: 324). MacIntyre sees in this character an amoral technician, disengaged from particular practices and traditions, one who uses reason as an instrument without regard for matters of purpose.

The bureaucratic manager MacIntyre describes is one who claims expertise in "techniques" for solving problems in a methodical, systematic, logical manner: observe the organization, identify the problem, construct a model that reduces the problem to a set of mathematical relationships, then solve the problem and implement the solution. To become such a manager, one must be "armed" with a set of tools-supposedly neutral rational principles that can be used to methodically identify and solve problems - without concern for questions of moral character or the need to bother with the particularities of place or tradition.

MacIntyre describes such a manager as part of his social criticism, both to awaken his reader (in order that one might recognize the worthlessness and barbarism of such a character) and to hold up a mirror. By reflecting on the emptiness of this character, MacIntyre hopes that his reader will become inclined to turn away from the fragmentation and self-alienation of this form of life. MacIntyre advances a series of criticisms of this character, charging that such a manager is a manipulator and a sham expert who is detached from concrete social practices while living a fragmented life, cultivating consumptive acquisitiveness and destroying local communities of virtue.

In addition to MacIntyre's criticisms of the bureaucratic manager, he has criticized both the market economy and applied ethics (MacIntyre 2008, MacIntyre 1984). Nevertheless, scholars in the fields of business ethics and organizational studies have found in MacIntyre's virtue ethics positive resources to think through the relationship between management and moral philosophy. ${ }^{1}$ My goal in this article is to extend this conversation in two ways.

First, with regard to the debate as to whether management is a "practice" with its own internal standards of excellence (according to MacIntyre's stipulative definition), I show that an affirmative answer rests on a distinction. I argue that management, like teaching, public speaking, writing, and coaching, is a "domain-relative practice" that both has its own internal standards of excellence and is always related to another particular domain. Second, I argue that the virtue of practical wisdom is required to pursue the standards of excellence internal to management as a domain-relative practice; in doing so, I call attention to three features of the virtue of practical wisdom.

I proceed in four steps. First, I explain MacIntyre's account of the virtues in light of his definition of a "practice." Second, I examine his distinction between "practices" and "institutions." Third, I explain what I mean by a "domain-relative practice" and defend the claim that it is helpful to conceive of management in those terms. Finally, I focus on several features of practical wisdom as a virtue that is both developed in and integral to the standards of excellence internal to management as a domain-relative practice. 


\section{MACINTYRE ON VIRTUES AND PRACTICES}

MacIntyre's virtue ethics is familiar to many. Because the argument that I develop in the later sections of this article extends and takes issue with features of MacIntyre's work, it is worthwhile to prepare the ground by reviewing several features of his thought.

In After Virtue, MacIntyre famously presents a three-stage account of the virtues. MacIntyre defines virtues as character traits_- "acquired human qualities"- that are excellent in so far as the possession and exercise of the trait enables the possessor:

1) to achieve those goods internal to social practices (MacIntyre 2007: 191);

2) to engage in the quest for self-knowledge and increasing knowledge of the good (MacIntyre 2007: 219); and

3) to have an adequate sense of the traditions (which provide both practices and individual lives with their necessary historical context) to which one belongs or which confront one (MacIntyre 2007: 223). ${ }^{2}$

In order to explain the first of these, MacIntyre tells the story of the chess-playingchild. ${ }^{3}$

Consider the example of a highly intelligent seven-year-old child whom I wish to teach to play chess, although the child has no particular desire to learn the game. The child does, however, have a very strong desire for candy and little chance of obtaining it. I therefore tell the child that if the child will play chess with me once a week I will give the child 50 cents worth of candy; moreover I tell the child that I will always play in such a way that it will be difficult, but not impossible, for the child to win, and that, if the child wins, the child will receive an extra 50 cents worth of candy. Thus motivated the child plays to win. (MacIntyre 2007: 188)

The story traces a transformation in the child. At first, the child is not interested in chess. Then, once the offer of money-for-candy is made, the child undergoes a change. Motivated by money-for-candy, the child is willing to learn to play and to strive for victory. MacIntyre goes on to make this point. "Notice however that, so long as it is the candy alone which provides the child with a good reason for playing chess, the child has no reason not to cheat and every reason to cheat, provided he or she can do so successfully" (MacIntyre 2007: 188). In this circumstance, were the adult called away from the chess table, it would be in the child's rational self-interest to cheat.

In the next part of the story, the child undergoes another transformation. MacIntyre asks us to imagine a later scene. The child has now learned to play chess, and the regular chess games have become a matter of routine. Imagine visiting the child now without any money. As MacIntyre writes, one can hope that

there will come a time when the child will find in those goods specific to chess, in the achievement of a certain highly particular kind of analytical skill, strategic imagination and competitive intensity, a new set of reasons, reasons now not just for winning on particular occasions, but for trying to excel in whatever way the game of chess demands. (MacIntyre 2007: 188) 
After this transformation, the child comes to recognize that there are excellences internal to the practice of chess, and that these excellences are worth pursuing for their own sake. Given the offer to play now, the child might well respond, "I don't care about the money or the candy. Let's just play." With this change in motivation, the temptation to cheat is reduced or obliterated. "Now if the child cheats, he or she will be defeating not me, but himself or herself" (MacIntyre 2007: 188).

MacIntyre uses the example of the chess-playing-child to show several transformations. Originally motivated by money-for-candy, the child agrees to take up the activity of chess-playing. After becoming initiated into the practice of chess, the child moves through an apprenticeship (perhaps unwittingly) and comes to learn that there are excellences internal to the practice of chess. In discovering the excellences internal to the practice, the child undergoes a change in motivation. Rather than being motivated primarily by the goods that come with the pursuit of success, the child comes to be motivated by the excellences integral to the practice.

MacIntyre narrates the tale of the chess-playing-child in order to clarify the special way in which he defines the notion of a social "practice":

By a "practice" I am going to mean any coherent and complex form of socially established co-operative human activity through which goods internal to that form of activity are realised in the course of trying to achieve those standards of excellence which are appropriate to, and partially definitive of, that form of activity, with the result that human powers to achieve excellence, and human conceptions of the ends and goods involved, are systematically extended. (MacIntyre 2007: 187)

MacIntyre's definition is stipulative; he acknowledges it "does not completely agree with current ordinary usage" including his "own previous use" of the word (MacIntyre 2007: 187). It has become widely quoted and debated in the scholarly literature (e.g., Miller 1994; Keat 2000).

To elucidate this stipulative definition, MacIntyre gives examples of activities that do and do not constitute practices. Tic-tac-toe, for example is not a practice; presumably it is not complicated enough. Football, architecture, and farming are practices, but MacIntyre rules out activities that are merely parts of those practices: throwing a football with skill, brick-laying and turnip-planting. MacIntyre's preferred examples of social practices are drawn from the arts, sciences, and games: painting, music, medicine, chemistry, baseball, chess, etc.

The story of the chess-playing-child illuminates a crucial distinction between goods that are internal to a practice and those that are external. External goods are "contingently attached" to an activity in the sense that they could be garnered by some other means. In the example, the money-for-candy is a good that is external to the practice of chess because the child could acquire those funds by engaging in any activity similarly incentivized. By contrast, internal goods can only be identified and recognized by the experience of participating in the practice in question. It follows that those "who lack the relevant experience are incompetent thereby as judges of internal goods" (MacIntyre 2007: 188-89).

Essential to MacIntyre's definition of "practice" are "standards of excellence that are appropriate to, and partially definitive of, a form of activity" (MacIntyre 
2007: 187). In order to appreciate such excellence, according to MacIntyre, one must first be initiated into the practice in question. Doing so involves subordinating one's own (initially poorly formed) judgments and preferences to the authority of the best standards of the practice:

If, on starting to listen to music, I do not accept my own incapacity to judge correctly, I will never learn to hear, let alone to appreciate, Bartok's last quartets. If, on starting to play baseball, I do not accept that others know better than I when to throw a fastball and when not, I will never learn to appreciate good pitching let alone to pitch (MacIntyre 2007: 190).

Once one has become apprenticed, one can work toward mastery of a practice by engaging in the debates about the goods internal to the practice, for it is precisely these debates that characterize the history and tradition of each practice. Entering a tradition, on MacIntyre's view, is more like entering a garden than entering a museum. He describes a tradition as a "historically extended, socially embodied argument, and an argument precisely in part about the goods which constitute that tradition" (MacIntyre 2007: 222).

MacIntyre's idea of "standards of excellence that are appropriate to, and partially definitive of, a form of activity" (MacIntyre 2007: 187) rejects subjectivist and emotivist analyses of judgment. Subjectivism and emotivism hold that any individual can take up a detached point of view to formulate one's own standards based on individual preferences. MacIntyre's counter-argument is phenomenological in character, as he invites his readers to consider their own experience: anyone who has ever entered into a practice as an apprentice recognizes that one must at first subordinate one's one judgments in order to learn the standards appropriate to the practice. Only with that foundation can one engage in debate about those standards.

MacIntyre's overarching purpose in providing this definition of social practices is to provide an account of the centrality of the virtues. In order to pursue the excellences that are internal to a social practice such as chess, it is crucial to acquire and develop a set of character traits. As MacIntyre claims, "it is not difficult to show for a whole range of key virtues that without them the goods internal to practices are barred to us" (MacIntyre 2007: 191). In After Virtue, MacIntyre focuses especially on justice, courage, and truthfulness (MacIntyre 2007: 192). The virtues are central to the moral life precisely because such habits make possible the pursuit of excellences internal to social practices. ${ }^{4}$

MacIntyre's notion of a practice has been fruitful for descriptions and moral interpretations of a wide range of social activities, and it also has given rise to a series of questions. Scholars in a number of disciplines and professions have debated whether various activities fit this definition. Is nursing a practice? Teaching? Journalism? Management? Business? ${ }^{5}$ In certain ways, MacIntyre's project seems to encourage these sorts of questions. For example, as I discuss below, MacIntyre engaged in an interview with Joseph Dunne on education in which the two debated the question of whether teaching is a practice. ${ }^{6}$

Despite provoking such debates, MacIntyre has not focused typically on questions about whether or not some activity is a practice; in particular, he has not addressed 
the question of whether or not management or business are practices. In After Virtue, he states explicitly that he wants to steer away from such debates: "The question of the precise range of practices is not at this stage of the first importance" (MacIntyre 2007: 188). We might ask in response, what is of "the first importance" with regard to the notion of a practice? MacIntyre wants to focus on two key concepts in his extended definition of a practice: 1) goods internal to a form of activity, and 2) standards of excellence that are appropriate to, and partially definitive of, a form of activity. He does so in order to re-focus attention on the character traits needed to pursue such goods.

Further, the terms of the debate about the range of practices have not remained steady; when asking whether business and/or management are practices, is it a debate about business, capitalism, or management? (Beadle 2008, Moore 2002). In some ways, these questions - whether management (or business) is a practice with its own internal goods - are not quite at the same level as MacIntyre's criticism. MacIntyre's charge is not directed primarily against "management." Instead, MacIntyre's criticism has been directed at the manager as a character, especially as this character embodies the philosophy of emotivism. Nonetheless, as I discuss in more detail below, MacIntyre's interview with Joseph Dunne, in which they debate whether teaching is a practice, seems to invite these sorts of questions. One way to re-situate the debate is to attend to MacIntyre's distinction between practices and institutions.

\section{MACINTYRE'S PRACTICE-INSTITUTION DISTINCTION}

In a series of articles, Geoff Moore has shown that, in order to draw out the implications of MacIntyre's virtue ethics and apply his framework to the management of business organizations, it is necessary to attend to MacIntyre's "practice-institution distinction" (Moore 2002, 2005a, 2005b, 2008; Moore and Beadle 2006). MacIntyre begins his explanation of the difference between a practice and an institution by citing examples: "Chess, physics and medicine are practices; chess clubs, laboratories, universities and hospitals are institutions" (MacIntyre 2007: 194). In terms of definition, MacIntyre distinguishes institutions from practices in terms of the ends sought by each. Practices are characterized as having internal goods and standards of excellence appropriate to the activity. In contrast, institutions are "characteristically and necessarily" (MacIntyre 2007: 194) concerned with external goods, especially money, power, and status.

The relationship between practices and institutions, in MacIntyre's account, is complicated. MacIntyre mentions five features of the relationship (MacIntyre 2007: 194):

1) Practices need institutions in order to be sustained.

2) Institutions "house" practices.

3) Practices and institutions are part of the same causal order.

4) Once established, practices and institutions concern themselves with and are attentive to different goods and purposes. 
5) The virtues are needed both to pursue the goods internal to the practice and to avoid the temptation to favor external goods to the neglect of the internal goods.

Implicit in these claims is a theory of the origin of institutions. Practices give rise to and depend on institutions. Institutions have their genesis and origin in social practices.

This account, which places institutions along with practices, serves MacIntyre's central goal of debunking the claims of emotivism, especially the notion that each individual can choose his or her own values. MacIntyre wants to show that the dispositions and attitudes that go with "choosing one's own values" make it impossible to pursue excellence. Rather, in order to pursue excellence, one must humble oneself to the standards of a practice and the excellences better known by those more masterful in the practice than oneself. Pursuing the excellences internal to a social practice such as chess involves an entire social nexus. Fellow practitioners might agree to form a chess club in order to serve the members. By organizing classes and tournaments, the members of the club are able to become more excellent practitioners. Thus, MacIntyre claims that it would be difficult for practices to survive "for any length of time unsustained by institutions" (MacIntyre 2007: 194).

While practices and institutions are intimately related, the two have separate goals. Practices aim at excellence (as measured by standards internal to the activity) while institutions aim at success (as measured by standards external to the activity). In pursuit of these goals, each is subject to distinct dangers and corrupting tendencies. Practices that are not institutionalized risk unsustainability. However, once a practice is institutionalized, the practice becomes vulnerable to the acquisitiveness of the institution. Since institutions are "characteristically and necessarily" concerned with external goods, especially money, power, and status, they are prone to the neglect of internal goods. MacIntyre claims, "We should therefore expect that, if in a particular society the pursuit of external goods were to become dominant, the concept of the virtues might suffer first attrition and then perhaps something near total effacement, although simulacra might abound" (MacIntyre 2007: 196).

MacIntyre claims, in an awkward and poorly constructed sentence, that institutions have "all the characteristics of a practice" (MacIntyre 2007: 194). Implicit in that subtle claim (and in the paragraphs that follow) is a distinction between two different kinds of institutions. Liberal, individualist, modern institutions (which aim to serve the community by providing the degree of order needed to allow each individual to pursue his or her own self-chosen conception of the good life) are distinct from ancient/medieval institutions. The difference between these two, according to MacIntyre, has to do with the role of the virtues in the work of sustaining an institution.

Within institutions in the ancient/medieval form, the virtues are necessarily exercised "by at least some of the individuals who embody it in their activities" (MacIntyre 2007: 195). The virtues are understood, at least by some of the institution's members, to be necessary for the sustenance of the institution. In contrast, modern liberal institutions purport to produce fair outcomes without relying on the virtues. Without the virtues, the institutional concern for external goods will 
tend to become dominant and the virtues needed to sustain the institution against consumptive and competitive desires will erode (MacIntyre 2007: 196). MacIntyre reminds his reader that, although external goods (such as wealth and prestige) can have a corrupting influence, these are in fact goods. Although his tone tends to suggest that external goods are corrupt, that is not MacIntyre's view. Wealth, status, and power are characteristic objects of human desire. Within the tradition of the virtues, justice and generosity pertain to the allocation of these goods. In a similar way, while MacIntyre is critical of modern institutional forms, he is not a critic of institutions. When MacIntyre claims that institutions have all the characteristics of a practice, he implies that making and sustaining institutions are activities with their own internal goods (MacIntyre 2007: 194).

MacIntyre's practice-institution distinction has been qualified and clarified by later discussion, both by MacIntyre and by scholars in organizational studies seeking to apply this schema. In a 1994 essay titled, "A Partial Response to My Critics," MacIntyre provides an example (widely quoted by commentators) of two fishing crews. One is a modern crew organized for the sake of profits; the other is a more traditional crew. We are asked to imagine someone who joins a traditional fishing crew, motivated at first perhaps initially by the pursuit of a wage, but who later acquires from the crew "an understanding of and devotion to excellence in fishing and to excellence in playing one's part as a member of such a crew" (MacIntyre 1994: 285). MacIntyre concedes that the goal of such a crew is to catch fish and to provide economic support to the crew's members, but as evidence that their goals also include the excellences internal to the practice of fishing, he points to the way such crews support one another in times of personal difficulties and exhibit a continuing allegiance to the crew and the fishing village through periods of economic hardship.

The fishing crew example illustrates MacIntyre's point that it is possible for the participants in a productive practice (such as the fishing crew) to be concerned with external goods while continuing allegiance to the internal goods of the practice. "The subordination of economic goods to goods of practice can be a rewarding reality" (MacIntyre 1994: 285).

The two fishing crews also embody the elements of MacIntyre's practice-institution distinction: practices are concerned with internal goods and standards of excellence appropriate to an activity. In order to be sustained, practices need to be institutionalized. Institutions must be attentive to external goods, especially money, power, and status. Practices without institutionalization risk unsustainability, while institutions are constantly tempted to pursue external goods to the neglect of internal goods. The virtues are needed both for the practitioner to pursue internal goods and for those charged with sustaining institutions to withstand the temptations that frequently accompany external goods.

The example and other elements of the practice-institution distinction raise a variety of questions. For example, given that it is difficult for practices to survive for any length of time unsustained by institutions, what sort of institution might support the fishing crew's practice? Can this same schema be applied to other sorts of productive activities? Farming? Mining? Manufacturing? Railroading? Retailing? Could an airline or an electric utility be understood using this schema? Could one 
apply MacIntyre's practice-institution schema to these businesses? Is it possible to conceive of corporations as institutions that house practices? ${ }^{7}$ What virtues would the manager of such an institution need? The task of this article is to argue based on this distinction between practices and institutions that management can be a domain-relative practice.

\section{MANAGEMENT AS A DOMAIN-RELATIVE PRACTICE}

In order to explain and defend my claim that it is helpful to conceive of management as a domain-relative practice, I begin with the published conversation between Joseph Dunne and Alasdair MacIntyre on teaching. Then I compare teaching with public speaking, writing, and coaching to draw out the notion of a domain-relative practice before showing that this notion is applicable to management.

The notion of a "domain-relative practice" is implicit in the published conversation that occurred between Joseph Dunne and Alasdair MacIntyre about education (Dunne 2002). Early in the conversation, Dunne asked MacIntyre to comment on a government report in Ireland that recommends that in schools, the headmaster or principal "should be replaced by a "chief executive"" (Dunne 2002: 3). Striking a polemical tone, MacIntyre criticized the tendency to conceive of the school as "a machine whose activities are to be understood as transforming input into measurable output" (Dunne 2002: 4). In this context, the teacher is thought of as one with technical expertise in raising test scores and producing outcomes for assessment. Instead of conceiving of the purpose of the school in terms of developing the powers and abilities of the student, i.e., "the whole cultural formation of the student," the ideal teacher in such a system is the one who can produce the highest measurable outcome at the lowest cost. Unsurprisingly, MacIntyre criticizes this model of education. He calls instead for an approach where each teacher "is engaged in initiating his or her students into some practice" (Dunne 2002: 5).

Dunne asked MacIntyre, "Can we helpfully construe teaching as itself a practice and see the curriculum itself as a set of practices into which students are to be initiated?" (Dunne 2002: 4). MacIntyre provided a long, somewhat wandering answer, portions of which were quite surprising to Dunne. Specifically, MacIntyre stated, "Teaching itself is not a practice, but a set of skills and habits put to the service of a variety of practices" (Dunne 2002: 5). The heart of MacIntyre's proposal was that teachers should think of themselves in terms of the disciplines they teach, "as a mathematician, a reader of poetry, an historian or whatever, engaged in communicating craft and knowledge to apprentices" (Dunne 2002: 5). Included in his answer, MacIntyre emphatically denied that teaching is itself a practice.

Dunne challenged MacIntyre's claim, both in the conversation and in a follow-up article and book (Dunne 2003, Dunne and Hogan 2004). In MacIntyre's response during the conversation, he dug in his heels, claiming that teaching is "never more than a means, that it has no point and purpose except for the point and purpose of the activities to which it introduces students. All teaching is for the sake of something else and so teaching does not have its own goods" (Dunne 2002: 9). 
Despite MacIntyre's stubborn claims, it seems clear that Dunne gets the better of this debate. Dunne concedes that teaching is not a sort of "domain-neutral expertise" (Dunne 2002: 7), but he goes on to show that it is beneficial to conceive of teaching as a practice according to MacIntyre's definition. Specifically, Dunne shows that teaching is a complex form of socially established cooperative human activity, that it contains its own internal standards of excellence, that it is the good of a certain kind of life, and that the dialectic between practice and institution is reflected in the case of teaching and school (Dunne 2002: 7-8). Further, as Dunne points out, MacIntyre makes several relaxed comments during the interview that support the claim that teaching is a practice; MacIntyre refers to the "ends of teaching" and "the practice or practices of teaching" (Dunne 2003: 353).

I propose that a way to resolve this debate is to think of teaching as a "domainrelative practice." This concedes MacIntyre's criticism of those who claim a supposed domain-neutral expertise while also granting Dunne's points that teaching is an activity with its own set of excellences, one that can be made into a form of life embodied in a practice and housed in relevant institutions such as schools, colleges, and universities.

In coining this phrase, "domain-relative practices," I am pointing to activities that 1) possess internal standards of excellence identifiable to practitioners, and 2) are always related to another particular domain. In each such case, familiarity with the particularities of the other related domain is an integral feature of the activity. By a "domain-relative practice," I mean more than the simple insight that each social practice is relative to its own particular domain. Obviously, the practice of medicine is related to the domain of health care, and the practice of mathematics is related to the domain of numbers, etc. Instead, I am drawing on a suggestion, made by MacIntyre in a number of places (MacIntyre 2007: 33-34, 218) that social practices can interlock such that we can refer to "a set of interlocking social practices" (D' Andrea 2006: 396). I am proposing that "domain-relative practices" always interlock with other practices. $^{8}$

My aim is to show that management can be conceived of as similar in this way to teaching, writing, speaking, and coaching: each of these is a social activity that has internal standards of excellence identifiable to practitioners, and each is also always relative to a particular domain: one teaches a subject, writes or speaks on a topic, coaches a sport, and so forth. There is no detached, pure, abstract, "Platonic form" of coaching. Similarly, teaching, public speaking, writing and managing are each socially embodied in two senses. Each of these is a social activity, discoverable always and only in a social context where the one engaging in the activity is related to other human persons. Additionally, each of these activities always has an interlocking relationship with some specific social context. In athletics, there are basketball coaches, baseball coaches, and so forth, but there are no coaches "in general."

To strengthen this description of domain-relative practices, I want to call attention to Aristotle's conception of the art of rhetoric. Aristotle, in his Rhetoric, agreed with Plato's criticisms of the sophists; like Plato, Aristotle found objectionable the sophists' use of persuasive speaking to gain personal advantage (1355b8-22). Public 
speaking is not simply the power to persuade an audience on any subject. For that reason, Aristotle did not dismiss rhetoric as an activity that is never more than a means to the goal of persuasion. Instead, he showed that rhetoric has its own internal standards of excellence, even as rhetoric is understood as one of an interlocking set of practices that is part of life in a political community..$^{10}$ On Aristotle's account, because the activity of public speaking always involves three components (a speaker, the speech, and the audience), there are three standards of excellence available in each instance: the character of the speaker, the contents of the speech, and the mood of the audience (1356a1-25). Artful speakers are excellent at embodying these excellences in their public speeches. Public speaking may be practiced on a wide range of topics, but it is foolish for a speaker to pretend to have more knowledge than one does. Every speech is on a topic, and the artful speaker needs to know one's topic.

Aristotle recognized that there is a complicated relationship between artful public speaking and the goal of persuasion. The excellence of an artful public speaker cannot simply be measured based on standards of success, for example, by courtroom victories, by election successes, or by the outcomes of gaining a majority of votes in a deliberative assembly determining a proposed policy. ${ }^{11}$ The function of rhetoric, according to Aristotle, "is not simply to succeed in persuading, but rather to discover the means of coming as near such success as the circumstances of each particular case allow" (1355b9-11). In order to embody rhetorical excellence, the artful speaker needs to practice a range of virtues, especially the virtue of practical wisdom (Garver 1995, 2004). Rhetoric, as conceived by Aristotle, fits the definition of a domain-relative practice that I stated above: it possesses internal standards of excellence identifiable to practitioners, and in each such speech, familiarity with the particularities of one's topic is an integral feature.

Considering the practice of coaching in athletics can illuminate the same points. ${ }^{12}$ Take the example of an excellent basketball coach. On the one hand, many of the qualities that make for an excellent basketball coach are the same qualities found in an excellent coach from any sport: abilities to motivate, communicate, carry out well-designed practice routines with appropriate training and drills for skills instruction and game preparation, adeptness at in-game coaching, and so forth. On the other hand, excellence at coaching basketball is specifically related to the game of basketball; an excellent basketball coach needs to have a great deal of skill that is specific to basketball: aiding one's athletes in improving the particular skills needed in basketball, stressing defense and teamwork, diagnosing opponent strategies, creating opportunities for open shots while limiting these in the opposing team, etc. If someone is very good as a basketball coach, it does not follow that the same person would be very good as the coach of a golf squad or a swimming team. Excellence as a coach is intimately tied to the coach's familiarity with the particular sport one is coaching.

As a brief aside, it will help to apply the distinction between success and excellence to the case of a basketball coach. Success is measurable in terms of outcomes while excellence is embodied in activities. Success at coaching is typically measured by counting the victories of a coach's team; excellence at coaching is more subtle, and is revealed in the activity of coaching and is recognizable to fellow practitio- 
ners or those familiar with the standards of the practice. Consider the case of Brad Stevens, the young basketball coach of the Butler University team that lost in both the NCAA 2010 and 2011 men's basketball championship games. Butler is a comparatively small school from a small conference. As such, it was a great success for the team to advance through the tournament, but they ultimately failed twice to win the championship. In the 2010 championship game, Butler's star player, Gordon Hayward, missed a long shot at the buzzer that would have completed a thrilling David-over-Goliath victory. Should Butler's loss in the 2010 championship game be considered a success or a failure? How should we evaluate the performance of Butler's coach in that game? How should we evaluate a coach whose team advances to the championship game and then loses? Measured in terms of success, Butler lost the 2010 and 2011 championship games. Focusing especially on Butler's 2010 championship defeat and evaluating it according to standards internal to the practice of coaching, it is possible to see the excellence in the performance of their coach, Brad Stevens: his ability to devise a successful strategy against an opponent with arguably superior athletes; his diagnostic abilities in pre-game preparation; his ability to motivate his athletes, communicating distinct roles to each and unifying them toward a common purpose; his calm focus during in-game decision making; his ability to coach his team to remain within striking distance in the final seconds; and so forth. The artful coach excels at discovering the means of coming as near to victory as the circumstances of each particular case allow. Coaching, then, is a practice with its own internal excellences even as it is always related to a particular domain, such as basketball.

Suppose that Butler's basketball coach, Brad Stevens, were suddenly thrust into the role of coaching a different sport, for example, a baseball team. What would it take for him to excel at coaching in baseball? Certainly, he could draw from many of the same excellences that are involved in coaching basketball, but he also would need to attend to the many ways in which the practice of baseball is different from basketball.

Someone might object that competitive sports such as basketball do not have internal standards of excellence, or that focusing on those is foolish. Wouldn't a basketball coach that pursues internal standards of excellence or the development of positive character traits (over and above winning) have a very short career? In response, I want to acknowledge that there is a complicated relationship between the goods of excellence and the goods of success. Excellent coaches usually have winning records, but the coach with the most wins is not always the most excellent coach. What if the coach inherited a team with superior athletes? What if the victories were secured by cheating or by encouraging one's athletes to cheat? These strategies may make a coach successful in terms of victories, but not excellent qua coach. At the same time, a coach that is excellent at strategy, diagnosis, communication, motivation, decision-making, and so forth, may or may not produce victories in particular situations, such as the case of the Butler men's basketball team in the 2010 and 2011 NCAA championship games. Coaching, as with any social practice that is artful, may be measured in terms other than a simple appeal to success such as counting victories. In this sense, excellence in coaching involves discovering 
the means of coming as near to victory as the circumstances of each particular case allow. Pursuing those excellences involves acquiring a set of character traits: determination, honesty, fairness, and so forth.

In a parallel manner, I am proposing that it is helpful to conceive of management as a domain-relative practice. In doing so, I agree with MacIntyre's criticism of the bureaucratic manager. MacIntyre's disapproval is directed against the character who, based on a supposed domain-neutral expertise in social organization, claims proficiency at organizing any social group to pursue a given end: increasing agricultural efficiency, making fishing operations more profitable, or knowing how to make the trains run on time. MacIntyre is not proposing that locomotive engineers and switchmen can run the railroad without anyone managing operations. Certainly MacIntyre's disapproval of the character of the manager is complicated. I am focusing here on one aspect of his criticism: the supposition that the manager can develop expert knowledge of an abstract rational method employing supposedly disinterested principles that can be applied to every social domain without regard for the particularities of specific practices and traditions.

This aspect of MacIntyre's criticism runs as follows. The character of the bureaucratic manager rests on a false set of metaphysical assumptions about the self; in pretending to take up a detached, disengaged perspective that applies supposedly atemporal principles to particular social contexts, such a manager is engaged in a metaphysical self-contradiction. This does not mean that there are no universal moral standards, nor is it reducible to a simple rejection of principles in ethics. As MacIntyre puts it in After Virtue, the contradiction lies in the manager's claim to simultaneously "pass judgment from a purely universal and abstract point of view" where "anyone and everyone can thus be a moral agent, since it is in the self and not in social roles or practices that moral agency has to be located" while at the same time, the manager claims expert authority, enjoying "their status in virtue of their membership within hierarchies of imputed skill and knowledge" (MacIntyre 2007: 32). The heart of the contradiction lies in a failure to recognize adequately the relationship between an abstract, atemporal realm of thought and the concrete, space-and-time setting of each circumstance. MacIntyre suggests that the managerial type he has in mind tends to make decisions by abstracting each situation and then treating it as an atemporal problem considered primarily in terms of efficiency and effectiveness. Doing so allows one to focus on certain features of the context while other aspects of the situation are neglected as non-rational, private values not subject to consideration. However, the claim that one can methodically identify and solve problems by solely attending to abstract concerns directs attention away from other features of a particular context that may be crucial: the particularities of place or tradition, the intentions and dispositions of those involved in the situation, or the impact of the decision on various stakeholders such as the workers, the suppliers, the consumers, the natural environment, and the broader society.

Regrettably, the sort of manager that MacIntyre criticizes is a well-known type. Nonetheless, a series of objections might be raised. As Whetstone has shown, the account of the manager as Weberian bureaucrat does not quite accord with the way that many flesh-and-blood managers act, speak, or make judgments (Whetstone 
2003: 344). Isn't it quite common for managers to act with concerns that extend beyond meeting the bottom line? Isn't there an alternative way to conceive of the manager that builds on standards of excellence that are internal to the activity of managing? Are there standards of excellence internal to the activities of managing?

To identify such standards, it helps first to describe the functions and activities of managing. To do so, we can draw from several classic works, especially those of Fayol and Mintzberg. Writing at the beginning of the twentieth century, Henri Fayol developed one of the first and most influential descriptions of the role of the manager. Fayol pointed to a handful of functions associated with the role of the manager: 1) planning, 2) organizing, 3) commanding, 4) coordinating, and 5) controlling (Fayol 1949). Fayol's account of the manager's role continues to shape the curricula and textbooks of most business schools and courses in management; several widely used texts have reduced these to four functions and then arranged a semester's worth of material in terms of planning, organizing, leading, and controlling. ${ }^{13}$ Henry Mintzberg's book, The Nature of Managerial Work (1973), focuses on activities (rather than Fayol's account in terms of functions). Mintzberg's account is based on time-study analyses of the activities performed by managers. Based on empirical data, Mintzberg identified ten distinct but highly interrelated roles: figurehead, leader, liason, monitor, disseminator, spokesperson, entrepreneur, disturbance handler, resource allocator, and negotiator (Mintzberg 1973: 93-94). From Fayol and Mintzberg, we learn that the function, activities, and role of the manager are complex; these include both administrative and leadership responsibilities. The role involves budgeting, scheduling, hiring, firing, allocating, implementing, monitoring, correcting, and a whole host of activities that we might associate with "administrative or managerial tasks.” The role also involves greeting, listening, planning, identifying, solving, communicating, motivating, delegating, mentoring, celebrating and many activities that we might associate with "leadership tasks."

Just as a basketball coach can be evaluated either in terms of success (typically measured in terms of victories) or excellence (according to the standards internal to coaching), so, too, a manager can be evaluated either according to some measurable outcome or by attending to the excellence internal to the activities of administering and leading. Management is done artfully insofar as it accords with internal standards of excellence.

At the same time, the manager's task involves administering and leading in an institutional setting where another practice or set of practices are housed. Just as there are no coaches or teachers per se (only coaches of one or more particular sports and teachers of one or more particular disciplines), so, too, management is a domain-relative practice. So, excellence in management always involves attending to the excellences of those practices housed in the institution that one is charged with managing. And, as with other practices, it is the virtues that make possible the pursuit of the excellences internal to managing.

Whetstone has suggested that ethics researchers might do more to listen to managers and the way they use virtue language. Whetstone proposed that teachers and researchers concerned with business ethics should increase their understanding of extant virtue language, "listening to what managers themselves say when discussing 
excellent managers" (Whetstone 2003: 344). In his empirical research, Whetstone listened to managers and those who are managed, attending to the language used to describe the excellences involved in managing well. Whetstone showed that contemporary managers, while certainly not schooled in the classical and medieval tradition of the virtues, employ with considerable articulation a moral language that "is essentially one of virtues and vices" (Whetstone 2003: 354). The traits reported in Whetstone's study correspond to a rather traditional list of moral virtues: honesty, trustworthiness, dedication, fairness, integrity, self-control, politeness, compassion, and loyalty (Whetstone 2003: 352). Whetstone also reported that those he studied listed several other traits: flexibility, good judgment, the ability to show perspective, and the ability to be innovative (Whetstone 2003: 352). These traits, it seems to me, are connected to practical wisdom, that is, the virtue that Aristotle called phronesis and St. Thomas Aquinas called prudentia. Indeed, it would seem that the central trait needed to pursue the excellences that are internal to management as a domain-relative practice is the virtue of practical wisdom.

\section{PRACTICAL WISDOM AS DEVELOPED IN AND INTEGRAL TO MANAGEMENT AS A DOMAIN-RELATIVE PRACTICE}

It is a somewhat curious feature of MacIntyre's After Virtue that, although he makes it clear that the virtues are acquired human qualities "the possession and exercise of which tends to enable us to achieve those goods internal to practices" (MacIntyre 2007: 191), he says comparatively little about the virtue that Aristotle considered central, namely, the virtue of practical wisdom. While this deficiency is rectified to some extent in MacIntyre's follow-up book, Whose Justice? Which Rationality?, he has done little to develop an account of practical wisdom as a virtue helpful for those charged with administrative and leadership responsibilities, that is, for those charged with managing institutions that house social practices. ${ }^{14}$ To address this shortcoming, I summarize the virtue of practical wisdom, discussing it in both the classical/medieval context and the literature of contemporary business ethics. Then I point to three features of practical wisdom developed in and integral to the pursuit of those standards of excellence internal to management as a domain-relative practice.

\section{Classical and Medieval Descriptions of Practical Wisdom}

The classic descriptions of the virtue of practical wisdom can be found in Book VI of Aristotle's Nicomachean Ethics and in questions 47-56 of the Secunda Secundae of St. Thomas Aquinas's Summa Theologiae. In sum, practical wisdom is the virtue whereby one acquires a habit of mind such that, in each case, one is excellent at 1) deliberating about what to do while attending to relevant particularities, 2) making in each instance a good judgment, and 3) carrying out such decisions in action. ${ }^{15}$ As such, the person of practical wisdom has actively developed excellent habits of deliberation, judgment, and execution.

While the virtue of practical wisdom involves the ability to find fitting means to accomplish a given end, it goes beyond tactical cunning. As Aristotle puts it, practical wisdom involves "calculating well toward some specific worthy end on 
matters where no exact technique applies" (Nicomachean Ethics 1140a28). In order for a manager to accomplish a given end efficiently and effectively, it may, in many cases, help to devise policies, procedures, regulations and routines so that similar cases can be treated in a similar manner, but this differs from the virtue of practical wisdom. Practical wisdom involves attending to the concrete particularities of each case, recognizing instances in which no exact technique or policy applies. In this sense, the person of practical wisdom, having developed a storehouse of knowledge that comes about through experience, is attuned to the relevant concrete particularities in each situation. Additionally, practical wisdom involves deliberating about whether a given end is worthy and conducive to a good life, both for oneself and for one's community.

Because this virtue involves a sort of foresight, Cicero translated Aristotle's Greek term, phronesis, with the Latin, providentia, denoting a kind of divine foresight. This Latin term was later contracted, so that the medievals used the term prudentia to denote wisdom in human action, especially the ability to foresee the consequences of action in each case. Centuries later, the term prudence took on negative connotations, so that a "prude" or prudish person came to be thought of as one who is unduly cautious, overly concerned with social decorum, or uneasy with normal human desires as they relate to sexuality, alcohol, or other potential sorts of mischief. The classical and medieval notion of practical wisdom is quite different from the modern sense of prudishness. At the heart of practical wisdom is the ability to reason well about action, bringing together sound principles with what is known about the past and the present to make good decisions.

In the traditional list of cardinal virtues, practical wisdom has held a primary place (even more important than courage, temperance, and justice) on the grounds that being precedes goodness (May 1995: 698; Pieper 1966). In order to make fitting and appropriate decisions, one must be disposed with a sort of "openness to being," that is, a willingness to receive and understand each situation as it is. This involves being rightly disposed to the reality of each circumstance in terms of the past, present, and future. In order to cultivate this disposition, the medievals pointed to memoria (an openness to the past that is free from falsification), docilitas (an ability to practice silence in order that one might listen to the fullness of each present moment), and solertia (an openness to the unexpected future).

Of course, it goes without saying that, all too often, contemporary managers lack practical wisdom, and they do so in a variety of ways. Some managers are hasty, blind to the concrete realities that surround a particular situation, inconstant, indecisive, thoughtless, negligent, or completely remiss in decision. Others are cunning, crafty, small-minded, insidious, fraudulent, and filled with guile or covetousness. ${ }^{16}$ Regrettably, there are too many instances of managers with these and other similar vices. Further, such managers at times achieve success as measured in external goods such as money, prestige, and power. Alas, in management as with most other social practices, the connection between excellence and success is imperfect. Nonetheless, these vices diminish or block the ability to pursue and extend excellence at the activities internal to managing. 
Although contemporary managers might not use the classical name of "practical wisdom," it is not difficult to see that in order to become excellent at management activities (planning, leading, organizing, monitoring, correcting, celebrating, etc.) it is necessary to develop excellent habits of deliberation, judgment, and execution. Of course, the social contexts in which managers work are diverse. Some front-line managers work in close proximity to those they manage, participating at times in the work itself while making countless managerial decisions, shifting quickly between the roles of disturbance handler, resource allocator, monitor and negotiator to instances of taking on the role of disseminator, liaison, figurehead, entrepreneur or leader. In contrast, high-level executives frequently work in relative isolation from those impacted by their management decisions and in contexts that require less role-shifting. In these diverse contexts, managers become susceptible to distinct vices. Those who become habituated to make repeated, quick decisions or whose managerial tasks occur under significant time constraints are prone to fall short with regard to the habits required to deliberate well: circumspection, caution, foresight with regard to large patterns and long-range implications, willingness to listen to and take counsel from sources that are typically quiet, and so forth. In contrast, executives in charge of large organizations who focus on large-scale goals are prone to the tendencies to ignore relevant concrete particularities and to become unduly concerned with the "success" of the institution at the expense of the good of individual human persons and the common goods engendered in the social practices of which the institution is a bearer.

\section{Practical Wisdom and the Contemporary Literature of Business Ethics}

Dennis Moberg has noted, "Practical wisdom has received scant attention in business ethics” (Moberg 2007: 535). Indeed, Moberg's 2006 Presidential Address to the Society for Business Ethics goes a long way to respond to that lacuna. In a similar way, Gary Weaver has written that among those concerned with business ethics and organizations, more attention "needs to be paid to the notion of practical wisdom" (Weaver 2006: 358). In the years since these comments were published, several writers have focused attention on practical wisdom (Schwartz and Sharpe 2010, Sison 2009, Clarke 2010, Melé 2010). Further, this recent interest among business ethicists in practical wisdom has forerunners; Robert C. Solomon, writing in the early 1990s, developed an Aristotelean approach to business ethics in which he treated phronesis under the name "good judgment" (Solomon 1992: 328-29; Solomon 1993: 174-79). Attending to these discussions bring into focus several questions.

What is Practical Wisdom?

Schwartz and Sharpe note that it is difficult to define practical wisdom without offering a formula that is "too precise to capture this expansive concept or too vague to be of much use" (Schwartz and Sharpe 2010: 25). Nonetheless, several recent writers offer updated Aristotelian accounts that helpfully define and explain this virtue (Fowers 2005: 117; Pellegrino and Thomasma 1993: 90; Morris 1997: 160-69). Moberg begins his account of practical wisdom with a dictionary definition: "the ability to judge rightly in matters relating to life and conduct" (Moberg 2007: 536). He im- 
mediately refines that definition: "Inspired mostly by the work of Aristotle, I define practical wisdom as a disposition toward cleverness in crafting morally excellent responses to, or in anticipation of, challenging particularities" (Moberg 2007: 536). Moberg goes on to explain the various parts of this definition. As a disposition, it is an active, stable trait. It has an intellectual element insofar as it involves ingenuity in crafting responses. It has to do with forming good judgments about actions, that is, with finding morally excellent responses. It involves excellence that is both reactive and proactive, that is, both crafting morally excellent responses and being able to anticipate. It deals with cases that are challenging, that is, where the best decision is not obvious. It entails an ability to make excellent decisions in light of the particularities of each context and circumstance. Moberg's refined definition is quite helpful, even as it invites further reflection and clarification.

\section{Is There a Distinct Virtue of Practical Wisdom for Business Management?}

Solomon's Aristotelean approach to business ethics raises a puzzle. On the one hand, Solomon occasionally referred to "business virtues" (Solomon 1992: 327, 332, 335-37). In particular, after discussing phronesis, Solomon turned his attention to "toughness," calling it a "true business virtue" and the "primary business virtue" (Solomon 1992: 337). On the other hand, Solomon asserted that business virtues are not opposed to the "virtues of civilized life" (Solomon 1992: 327). Are business virtues different from the virtues of a good human life? Is there a distinct type of practical wisdom appropriate to managers? To resolve this puzzle, it is worth noting that Aristotle considered a similar question, but in the context of politics (1141b18-35). He asked whether phronesis is different in the context of one's own life compared to making decisions about managing one's family or making political decisions about the well-being of one's community? To think through this question, Aristotle stated, "Political wisdom and practical wisdom are the same state of mind, but their essence is not the same" (1141b18). What does this mean? As Aristotle unfolds his point, he shows that phronesis is developed through experience in life. A young person may be intellectually astute in mathematics and quite capable at abstracting from a concrete situation. By dealing with abstractions, the mathematician and geometer focus on less-than-what-one-sees, as it were. In contrast, phronesis requires, in a complex social context, the ability to see unnoticed particularities and possibilities. Acquiring practical wisdom generally takes experience, but the sort of experience that is required must be relevant to the sort of decision required. Grandmother may have experience in life, and hence she may be prudent in making good decisions about her life or her home, but that does not mean that she has all that it takes to make good decisions in the context of a business organization or a political community. Because management is domain-relative, excellence at managing requires familiarity with the relevant particulars, along with an ability to craft morally excellent responses to, or in anticipation of, challenging particularities. 
Are There Specific Business Contexts that Tend to Require the Exercise of

Practical Wisdom?

In a certain sense, challenging particularities can arise in virtually any circumstance in which a manager is required to make a decision. Moberg identified four such contexts that frequently arise in business (Moberg 2007: 537-40).

1) Information Uncertainties and Ambiguities. Mangers frequently find themselves faced with a difficult decision because key information is lacking or incomplete, especially information about the intentions of one or more of the people involved in a situation. The person of practical wisdom is able to recognize the need for more information and to know how to gather what is needed to decide well.

2) Execution Binds. Managers sometimes encounter circumstances in which the most ethical alternative seems to involve significant cost. Practical wisdom encourages one to consider whether there is a way to execute the best option in precisely the right manner, while diminishing the foreseen harm, so the action is done at the right time toward the right person for the right reason in the right way.

3) Moral Dilemmas. Managers find themselves in situations where it seems that choosing one good thing will require a trade-off that diminishes another good: Selfinterest or the good of the group? Justice or mercy? Truth or loyalty? Short-term profit or long-term sustainability? Practical wisdom rarely reduces these dilemmas to a simple ranking system; attentive to the specifics of each case, the person of practical wisdom seeks to craft an imaginative decision well-suited to the circumstance.

4) Ethical Leadership Predicaments. Managers are frequently called upon to lead a social unit and to develop new policies in a context in which some of the people who will be affected by the policy may be opposed to the proposed direction. The person of practical wisdom is attuned so that decisions are made in an appropriate manner, attending to the concerns of those who may disagree without producing a stalemate, undue distrust, or disgruntlement.

Certainly Moberg and Weaver are correct in suggesting that business ethicists could do more to attend to the virtue of practical wisdom. My goal now is to add to the conversation by bringing into focus three additional aspects of the virtue of practical wisdom that come with viewing management as a domain-relative practice.

\section{Practical Wisdom Begins with "Knowing What You Don't Know"}

A brief anecdote should help bring into focus one of the features of the virtue of practical wisdom. A friend had a career working for an electric power utility company. For twenty years, he was a lineman before moving into a management position. In his management position, he and the other managers were given access to information about the electrical system as a whole in the large metropolitan area where he worked. He had little formal training in thinking about the system as a whole or in managing a large organization, so his move into a management position required that he learn to supplement his years of field experience with a different sort of thinking. He found himself working with managers who moved into the position through a different path; these managers had significant formal education, and they were generally younger and less experienced in the company. 
During severe storms or after other damaging incidents, his management position required him to make decisions impacting the way that electrical service could be restored or maintained to many thousands of people. In that context, he would sometimes complain about the way that his better educated colleagues or supervisors would make decisions. Specifically, he complained that they would sit at their desks, observing the lights on the grid, with little or no knowledge about the specific electric poles and transformers referred to on the computerized model of the grid or about the crew members and linemen who would be called out to respond to the power outage. There were many instances where he knew, based on years of past experience, a more efficient way to address a particular problem than the one proposed by his peers or superiors. Armed with abstract theories and degrees certifying their knowledge and expertise, they sometimes made poor decisions because of their lack of familiarity with the infrastructure and the crews charged with maintaining it. Further, he was sometimes in a position to provide useful information to his superiors, had they only asked.

The point of this anecdote is that it is a common vice for an individual with expert knowledge, especially of an abstract, theoretical sort, to think one knows more than one really does. Practical wisdom involves a sort of humility, that is, the habit of recognizing what one does not know. Once one becomes awakened to one's lack of knowledge (along with a recognition that such knowledge is needed in order to make good decisions), one is then motivated to seek the necessary knowledge. For those charged with managing, such humility can be a difficult aspect of practical wisdom, because it might seem to undermine the confidence apparently needed in a strong leader.

The decision-making activities of managing always interlock with other social practices. When managers get ahead of their own knowledge, they frequently make poor decisions. In order to plan, organize, and lead well, a manager needs more than formal analysis or a description of how one's institution is "supposed" to work; one needs to understand the social practices of one's employees, customers, suppliers, and others. Especially for managers and executives who are more removed from front line employees and the social practices housed in one's institution, it is all too easy to become isolated and to presume that one knows more than one does.

\section{Practical Wisdom Involves Experiential Knowledge of Particulars}

With the recent popularity of Malcom Gladwell's book Blink, there has been increased interest in and debate about a phenomenon that Gladwell calls "thinking without thinking." Gladwell's book begins with the story of a statue purportedly made in ancient Greece recently purchased by a prominent museum. When suspicions are raised about the sculpture's authenticity, art appraisers with years of experience in ancient Greek sculpture are asked to evaluate the statue. Almost immediately, each expresses with confidence that the statue is a forgery. With a brief look, the appraisers judge that something is "just wrong" about the statue. Without giving a scientific account, the appraisers describe their judgments using terms more commonly associated with the senses: the sculpture "stinks" or it leaves "a bad taste." 
Eighteen months later, through careful chemical testing of the stone, it was verified that the statue was indeed a forgery (Gladwell 2005: 3-8).

What is the nature of the sort of knowledge that the art appraisers had? In what sense did they "know" that the statue was not authentic? What is this phenomenon that Gladwell aptly names "thinking without thinking," and how is it different from "real thinking," in which one can provide good reasons or evidence to support one's conclusions?

In the case of the fake statue, we can distinguish between the sort of knowledge provided by the appraisers and the scientific evidence based on chemical analysis of the stone. For the appraisers, judgment was based on experience with particular authentic statues. For the scientists, judgment was based on their ability to measure evidence against universal standards.

This distinction can be used to explain the kind of information that managers frequently use to make decisions. It goes without saying that managers are sometimes required to make time-sensitive decisions and that they frequently do not have the time or resources to gather scientifically verifiable information to support a particular decision. Further, the uniqueness of a particular case may be such that it is impossible, or nearly impossible, to gain scientific evidence to support a required decision.

Practical wisdom requires knowledge of both abstract, universal truths and awareness of the concrete particularities of each action. Correct judgments are frequently based on experience without scientific understanding. In instances where someone has a great deal of experience, experiential knowledge of particulars may be quite reliable. As Aristotle notes, a person who has practical experience but an inability to articulate that sort of knowledge in theoretical terms is a more reliable guide to good decisions than a person who has theoretical understanding and an inability to recognize the way those abstract truths are embodied in a particular instance. "If a man knew that light meats are digestible and wholesome, but did not know which sorts of meat are light, he would not produce health, but the man who knows that chicken is wholesome is likely to produce health" (NE 1141b18-20).

Decisions that call for practical wisdom frequently require experiential knowledge of particulars. Aristotle and St. Thomas Aquinas referred to this kind of knowing as "particular reason." Because this kind of knowing is developed through experience, it is common for people with a great deal of experience in a certain domain to have such knowledge. While it is possible for this kind of knowledge to be organized and systematized, it need not be. It is common for people with experience to be immersed in a set of practices and a tradition that makes them attentive to relevant particularities needed for good decision-making. Although it is a dictum of Aristotelian philosophy that "the senses know particulars while the intellect knows universals," this actually oversimplifies Aristotle's considered view. In addition to sense awareness and intellectual knowledge, Aristotle describes a sort of experiential knowledge of particulars that is distinct from the external senses and the intellect. The medievals had several names for this knowledge of particulars; they sometimes called it discursive, collative, estimative or cogitative (Klubertanz 1952: 161). This cogitative power involves a pre-reflective ability to attend to an organized whole, perceiving it as harmful or beneficial while also seeing it as connected to other 
realities. In practical matters, it attends to the particularities of each instance, for every action involves something unique.

Recognizing that management is a domain-relative practice involves an awareness that management decisions impact the persons, practices, and traditions housed in the institution. In order for managers to be excellent at planning, organizing, leading, and so forth, they need to be able to make good decisions, and those require knowledge that is both abstract and concrete. Along with formal, theoretical principles, it is necessary to have relevant information about the practices that are housed in the institution one manages. So, part of practical wisdom involves openness to the experiential knowledge of particulars as it is embodied in the people and practices that are part of the institution.

\section{Practical Wisdom Includes Reasoning with Others about the Worthiness of Ends}

In a certain sense, practical wisdom involves the ability to reason well for the realization of a particular goal. However, in a fuller and deeper sense, practical wisdom involves the ability to reason well about human affairs generally. For example, it takes a sort of practical wisdom in military affairs to know what is required to bring about victory in a particular case. However, in the case of a Pyhrric victory, where devastating and irreplaceable casualties accompany success, the intellectual acumen of the strategist clouds the ability to reflect on the broader social and political purposes for seeking to win.

In the context of contemporary management, I have suggested that excellence at the activities that are internal to managing as a domain-relative practice requires the development and exercise of the virtue of practical wisdom. On the one hand, this involves calculating well toward some specific end by finding an appropriate course of action suitable to the concrete particularities of the situation. On the other hand, it also involves a willingness to question whether the given ends that one is pursuing are worthwhile, both for oneself and for others.

Practical wisdom, understood this way, involves a willingness to allow given ends to be called into question such that alternatives are treated as more than nonrational preferences. In this way, practical wisdom involves crafting morally excellent responses not only to particular decisions, but also to large questions. How might short-term profit be balanced with long-term sustainability? How might the goals of one's firm or unit be balanced with the well-being of the community or geographical region in which one's firm operates? How might the concerns of one's unit for efficiency and effectiveness be balanced with the recognition that the members of one's unit are persons with capacities and gifts, many of which go well beyond those that are realized through their work? How might those impacted by the activities of one's unit be invited at times to participate in common deliberation about the ends being pursued by the enterprise?

Understood this way, reason is not simply an abstract, disengaged, detached instrument. Reasoning about ends and evaluating given purposes occurs within a community and between communities, especially when objections are raised and 
considered. For such reasoning to go well, the interlocutors need to be willing to listen to alternative proposals and the concerns that give rise to them on their own terms.

I am not suggesting that managers must become philosophers-at least not in the sense that managers must give themselves over completely to the task of deliberating about questions of human purpose. However, I am suggesting that it is worthwhile at times to evaluate the given ends of one's organization and to engage with others about such questions, seeking to reason together with others about the kinds of lives we want to lead and about the kinds of communities we want to shape. Further, I am suggesting (with MacIntyre) that the tendency to think that reason is merely an instrument for efficiently and effectively bringing about a chosen end is diminished and hollow. So, I am suggesting that managers need practical wisdom, both in the sense that they need to attend to relevant particularities in order to accomplish given purposes and in the sense that they need to evaluate whether the ends proposed in their planning and organizing are conducive to a good life.

Another way to explain this point is to note that the virtue of practical wisdom involves two sorts of reasoning that are not widely recognized in modern contexts. In the previous section, I pointed to the notion of particular reason; of course, a great deal more could be said about this aspect of rationality. In a similar way, a great deal more could be said about the substantive reasoning needed in order to take up a rational evaluation of purposes. For now, suffice it to say that the virtue of practical wisdom involves the ability to evaluate the ends that one is pursuing in order to judge with others whether those are conducive to a good human life, both for oneself and for others.

In conclusion, I have argued that it is helpful to conceive of management as a domain-relative practice; it is a practice composed of activities with internal standards of excellence and it is always related to another particular domain. In order to become excellent at managing, it is necessary to develop a set of character traits; chief among these is the virtue of practical wisdom. Practical wisdom is the habit of mind whereby one is excellent in each case at finding the available means to accomplish a worthy end. This involves the humility to recognize when one lacks crucial information, the ability to attend to relevant particular details, and the ability to make good judgments as to whether the given end is worthwhile. ${ }^{17}$

\section{NOTES}

1. See Schwartz and Sharpe 2010, Dobson 2009, Sison 2009, Beadle and Moore 2008, Moore 2008, Hine 2007, Beadle and Moore 2006, Dawson and Bartholomew 2003, Moore 2002, du Gay 1998, Brewer 1997, Dobson 1997, Wicks 1997, Dobson 1996, Wicks 1996, Horvath 1995, Mangham 1995, Nash 1995, Randels 1995, McCann and Brownsberger 1995, Santilli 1984.

2. Beyond these three layers, MacIntyre revised his account of the virtues in his 1999 book, Dependent Rational Animals. He added a fourth layer that flows out of the acknowledgement that human beings are animals. Acknowledging that we are animals brings to light the role of vulnerability and dependence in human life. Our lives begin in a state of radical dependence. Typically, each human depends upon the gracious hospitality of one's mother. Her actions while one is developing in utero impact one's life, and the actions that our caregivers directed toward us during infancy and childhood impact us as well. Further, at any given moment of our lives, we are vulnerable to various injuries and diseases in which we may need the support of others. And many of us will reach a chapter of our lives when we rely upon others for care. With these 
features of our humanity in mind, MacIntyre points to a set of character traits that enable us to flourish as dependent animals. On MacIntyre's considered account, the virtues are acquired character traits that enable us to excel in social practices, our individual lives, our shared lives, and our lives as vulnerable, dependent animals.

3. It is always difficult to tell which parts of a philosopher's work will be studied in the future, but it seems likely that for generations, scholars will discuss MacIntyre's story of the "chess-playing-child.” David Solomon, during a panel presentation at University College Dublin on March 6, 2009, suggested that a hundred years from now, philosophers will continue to discuss MacIntyre's story of the chess-playing-child. In a private conversation on that weekend, Solomon (who is the Director of the Center for Ethics and Culture at the University of Notre Dame, where MacIntyre has held a chair) stated to me that MacIntyre has said on multiple occasions that he considers this to be his own most important contribution to moral philosophy.

4. In the Postscript to the second edition of After Virtue, MacIntyre clarifies this example further in response to objections raised by Samuel Scheffler. See MacIntyre 2007: 272-75.

5. See Sellman 2008, Noddings 2003, Dunne 2003; Lambeth 1990, Brewer 1997, Beadle 2008, Moore 2002.

6. In the literature of business ethics, MacIntyre's definition of a practice and his treatment of the manager has sparked debate from the time of the publication of the first edition of After Virtue in the early 1980s. In one explicit challenge, Kathryn Balstad Brewer takes issue with MacIntyre's characterization of management, arguing that management has its own internal goods. She concludes, "Management is a practice, and it can be a virtuous one" (Brewer 1997: 832). Geoff Moore points to and extends the debate in a series of articles (Moore 2002, 2005a, 2005b, 2008), and Moore's position has been challenged and qualified (Beadle 2008).

7. As noted at the beginning of this section, Geoff Moore has examined the practice-institution distinction in a series of papers. Moore has suggested that "MacIntyre's schema can be applied directly to business as a practice and to corporations as institutions" (Moore 2002: 23). Moore extends this analysis in several later essays (Moore 2005a, 2005b, 2008). Moore claims that it is the special function of management to provide administrative support to the "core-practice" housed in the institution and to protect the practice from the corrupting tendencies of institutions. Moore's claim, that business is (or can be) a practice, has been challenged by Ron Beadle, who argues that Moore has failed to distinguish between the "business-ofa-craft" and "business-qua-business" (Beadle 2008: 230).

8. Christopher Higgins, in a recent book-length manuscript published in the Journal of Philosophy of Education, extends the Dunne-MacIntyre conversation and the question of whether teaching is a practice. Similar to the notion of "domain-relative practices" developed here, Higgins develops the idea of a "parapractice," which he explains by writing, "Many practices, especially those that have communication built into them, attract cultures of criticism, interpretation, and commentary. These are situated neither wholly within nor wholly without the artistic and athletics practices (to choose the most obvious examples) they serve to explicate. Such para-practices tend to be interstitial; an architecture critic may be part newspaperman, part architect, and part art historian; a baseball broadcaster will have one foot in the world of baseball and one foot in the world of broadcast journalism" (Higgins 2010: 260).

9. Another way to clarify my point would be to employ the medieval doctrine of analogy. For example, a basketball coach and a baseball coach are both engaged in the same practice, analogically understood. That both are "coaches" might seem puzzling when we limit the use of language to only univocal or equivocal uses.

10. For an outstanding summary of Aristotle's Rhetoric that provides a philosophical interpretation of Aristotle's Rhetoric that puts that text into conversation with MacIntyre's definition of a practice, see Eugene Garver, Aristotle's Rhetoric: An Art of Character (Garver 1995).

11. For Aristotle's claim that public speaking has its own standards of excellence, see his Rhetoric, 1356a1-3. I have found very illuminating Garver's use of MacIntyre's categories in his explanation of Aristotle's Rhetoric.

12. I am limiting my discussion of "coaching" to its natural home in the domain of athletics. Over the last several decades, the notion of a coach has been broadened. There are many people now claiming expertise in coaching, including not only singing coaches and acting coaches, but also career coaches, dating coaches, personal life coaches, etc. 
13. For examples, see S. Robbins and M. Coulter, Management (Robbins and Coulter 2009) or R. Daft, Management (Daft 2009). Both of these textbooks, issued in multiple editions with updated examples, use a fourfold framework drawn from Fayol.

14. As Dennis Moberg put it, "MacIntyre's After Virtue is known more for reclaiming virtue ethics than for situating practical wisdom at its core" (Moberg 2007: 536).

15. For a helpful summary and explanation of this virtue, see Josef Pieper's treatment of prudence in The Four Cardinal Virtues (Pieper 1966).

16. These are the vices that St. Thomas Aquinas lists as forms of imprudence. See his Summa Theologiae, II-II, 53-55.

17. Portions of this article were presented at both the Second Annual Conference of the International Society for MacIntyrean Inquiry and the Lincoln University Conference on the Thought of Alasdair MacIntyre. I am grateful to questions from the conference participants. In addition, this article benefited from questions and suggestions raised by the editors of this special issue and the referees.

\section{REFERENCES}

Aristotle. 1941. The Basic Works of Aristotle, ed. R. McKeon. New York: Random House. Beadle, R. 2002. "The Misappropriation of MacIntyre," Reason in Practice 2: 45-54. 2008. "Why Business Cannot Be a Practice," Analyse und kritik 30: 229-41.

Beadle, R., and G. Moore, eds. 2006. "MacIntyre on Virtue and Organization," Organization Studies 27: 323-40.

eds. 2008. Philosophy of Management 7 (Special issue devoted to MacIntyre, empirics and organisation): 1-143.

Brewer, K. B. 1997. "Management as a Practice: A Response to Alasdair MacIntyre," Journal of Business Ethics 16: 825-33.

Clarke, C. 2010. "Practical Wisdom and Understanding the Economy," Journal of Management Development 29: 678-85.

Daft, R. 2009. Management, 9th ed. South Western College.

D'Andrea, T. 2006. Tradition, Rationality, Virtue: The Thought of Alasdair MacIntyre. Ashgate.

Dawson, D., and C. Bartholomew. 2003. "Virtues, Managers and Business People: Finding a Place for Macintyre in a Business Context," Journal of Business Ethics 48: 12738.

Deetz, S. 1995. "Character, Corporate Responsibility and the Dialogic in the Postmodern Context: A Commentary on Mangham," Organization 2: 217-25.

Dobson, J. 1996. “The Feminist Firm: A Comment,” Business Ethics Quarterly 6: 227-32. 1997, "Macintyre's Position on Business: A Response to Wicks," Business Ethics Quarterly 7: 125-32.

.2009. “Alasdair Macintyre's Aristotelian Business Ethics: A Critique," Journal of Business Ethics 86: 43-50.

Du Gay, P. 1998. "Alasdair MacIntyre and the Christian Genealogy of Management Critique," Cultural Values 2: 421-44.

Dunne, J. 2002. "Alasdair MacIntyre on Education: In Dialogue with Joseph Dunne," Journal of Philosophy of Education 36: 1-19. 
2003. "Arguing for Teaching as a Practice: A Reply to Alasdair MacIntyre," Journal of Philosophy of Education 37: 353-69.

Dunne, J., and P. Hogan. 2004. Education and Practice: Upholding the Integrity of Teaching and Learning. Oxford: Blackwell.

Fayol, H. 1949. General and Industrial Management, trans. C. Storrs. London: Sir Isaac Pitman and Sons (originally published in 1916).

Fowers, B. J. 2005. Virtue and Psychology: Pursuing Excellence in Ordinary Practices. Washington, D.C.: American Psychological Association.

Garver, E. 1995. Aristotle's Rhetoric: An Art of Character. Chicago: University of Chicago Press.

2004. For the Sake of Argument: Practical Reasoning, Character, and the Ethics of Belief. Chicago: University of Chicago Press.

Gladwell, M. 2005. Blink: The Power of Thinking without Thinking. New York: Little, Brown, and Company.

Higgins, C. 2010. “The Good Life of Teaching: An Ethics of Professional Practice," Journal of Philosophy of Education 44: 189-478.

Hine, J. 2007. “The Shadow of MacIntyre's Manager in the Kingdom of Conscience Constrained," Business Ethics: A European Review 16: 358-71.

Horvath, C. 1995. "Excellence v. Effectiveness: Macintyre's Critique of Business," Business Ethics Quarterly 5: 499-532.

Keat, R. 2000. Cultural Goods and the Limits of the Market. London: Palgrave Macmillan. 2008. "Practices, Firms and Varieties of Capitalism," Philosophy of Management 7: 17-91.

Klubertanz, G. 1952. The Discursive Power. St. Louis: Modern Schoolman.

Knight, K., ed. 1998. The Macintyre Reader. London: Polity Press.

Lambeth, E. 1990. "Waiting for a New St. Benedict: Alasdair MacIntyre and the Theory and Practice of Journalism," Journal of Mass Media Ethics 5: 75-87.

MacIntyre, A. 1984. "Does Applied Ethics Rest on a Mistake? The Monist 67: 598-613.

. 1985. Whose Justice? Which Rationality? Notre Dame, Ind.: University of Notre Dame Press.

1994. "A Partial Response to My Critics," in After MacIntyre, ed. J. Horton and S. Mendus. Cambridge: Polity Press.

1999. Dependent Rational Animals. London: Duckworth.

2007. After Virtue, 3rd ed. Notre Dame, Ind.: University of Notre Dame Press (originally published in 1981).

. 2008. Alasdair MacIntyre's Engagement with Marxism, ed. P. Blackledge and N. Davidson. Leiden: Brill Academic Publishers.

MacIntyre, A., and J. Dunne. 2002. "Alasdair MacIntyre on Education: In Dialogue with Joseph Dunne," Journal of Philosophy of Education 36: 1-19.

Mangham, I. 1995. “MacIntyre and the Manager,” Organization 2: 181-204. 
May, William F. 1995. "The Virtues of the Business Leader," in On Moral Business: Classical and Contemporary Resources for Ethics in Economic Life, ed. M. L. Stackhouse, D. McCann, and S. J. Roels, with P. N. Williams. Grand Rapids, Mich.: William B. Eerdmans Publishing, 692-700.

McCann, D., and M. L. Brownsberger. 1995. "Management as a Social Practice: Rethinking Business Ethics after MacIntyre," in On Moral Business: Classical and Contemporary Resources for Ethics in Economic Life, ed. M. L. Stackhouse, D. McCann, and S. J. Roels, with P. N. Williams. Grand Rapids, Mich.: William B. Eerdmans Publishing Co.: 508-13.

Melé, D.: 2010. "Practical Wisdom in Managerial Decision Making," Journal of Management Development 29: 637-45.

Miller, D. 1994. Virtues, Practices, and Justice in After MacIntyre, ed. J. Horton and S. Mendus. Notre Dame, Ind.: University of Notre Dame Press.

Mintzberg, H. 1973. The Nature of Managerial Work. New York: Harper \& Row.

Moberg, Dennis J. 2007. "Practical Wisdom and Business Ethics," Business Ethics Quarterly 17(3): 535-61.

Moore, G. 2002. "On the Implications of the Practice-Institution Distinction: Macintyre and the Application of Modem Virtue Ethics to Business," Business Ethics Quarterly 12: 19-32.

. 2005a. "Corporate Character: Modem Virtue Ethics and the Virtuous Corporation," Business Ethics Quarterly 15: 659-85.

.2005b. "Humanizing Business: A Modern Virtue Ethics Approach," Business Ethics Quarterly 15: 237-55.

. 2008. "Re-Imagining the Morality of Management: A Modern Virtue Ethics Approach," Business Ethics Quarterly 18: 483-511.

Moore, G., and R. Beadle. 2006. "In Search of Organizational Virtue in Business: Agents, Goods, Practices, Institutions and Environments," Organization Studies 27: 369-89.

Morris, Tom. 1997. If Aristotle Ran General Motors. New York: Henry Holt.

Nash, L. 1995. "Whose Character? A Response to Mangham's 'MacIntyre and the Manager," Organization 2: 226-32.

Noddings, N. 2003. Is Teaching a Practice?," Journal of Philosophy of Education 37: 24151.

Pellegrino, E., and D. Thomasma. 1993. The Virtues in Medical Practice. Oxford: Oxford University Press.

Pieper, J. 1966. The Four Cardinal Virtues. Notre Dame, Ind.: University of Notre Dame Press.

Randels, G. 1995. "Morality and the Manager after MacIntyre: A Response to Mangham," Organization 2: 205-11.

Robbins, S., and M. Coulter. 2009. Management, 10th ed. Upper Saddle River, N.J.: Prentice Hall.

Roberts, J. 1984. “The Moral Character of Management Practice," Journal of Management Studies 21: 287-302. 
Santilli, P. 1984. "Moral Fictions and Scientific Management," Journal of Business Ethics 3: $279-86$.

Schwartz, B., and K. Sharpe. 2010. Practical Wisdom. New York: Riverhead.

Schwartz, M. 2009. "Moral Vision: Iris Murdoch and Alasdair MacIntyre," Journal of Business Ethics 90: 315-27.

Sellman, D. 2008. "Alasdair MacIntyre and the Professional Practice of Nursing," Nursing Philosophy 1: 26-33.

Sison, A. 2009. "Practical Wisdom and the Practice of Business: What Can We Learn from MacIntyre?," available at www.stthomas.edu/cathstudies/cst/conferences/Practical Wisdom/PracticalWisdom/Sisonpaper.pdf. Proceedings of the conference, "The Business of Practical Wisdom: An Exploration of Virtue and Business within the Catholic Social Tradition.” Eichstätt-Ingolstadt, Germany.

Solomon, R. 1992. "Corporate Roles, Personal Virtues: An Aristotelean Approach to Business Ethics,” Business Ethics Quarterly 2: 328-29. 1993. Ethics and Excellence. Oxford: Oxford University Press.

Thomas Aquinas. 1948. Summa theologica. New York: Benziger Bros.

Weaver, G. R. 2006. "Virtue in Organizations: Moral Identity as a Foundation for Moral Agency. Organization Studies 27: 341-68.

Weber, M. 1947. The Theory of Social and Economic Organization, trans. A. M. Henderson and T. Parsons. New York: Free Press.

Whetstone, T. 2003. "The Language of Managerial Excellence: Virtues as Understood and Applied," Journal of Business Ethics 44: 343-57.

Wicks, A. 1996. "Reflections on the Practical Relevance of Feminist Thought to Business," Business Ethics Quarterly 6: 523-31.

1997. "On MacIntyre, Modernity and the Virtues: A Response to Dobson," Business Ethics Quarterly 7: 133-36. 